\title{
UNHOLY PRACTICES AMONG YOUTHS IN NIGERIA: VENOMS BREEDING TO A DISJOINTED SOCIETY
}

\author{
Babatope Matthew Ajiboye*, ORCID: 0000-0002-7992-3099 \\ Department of Peace and Conflict Studies, Federal University Oye-Ekiti, Nigeria \\ *babatope.ajiboye@fuoye.edu.ng
}

Received: 02.22.2021

Accepted: 04.05.2021

\begin{abstract}
Before the year 1990 and up to the late 1990s, Nigeria was ravaged by what was known then as "Advanced Free Fraud" christened (419) and "Trades of Narcotic Drugs". After more than two decades, a new set of unholy practices have found its way into the fabric of the society and have consistently proven to be worse than the duo of "419" and "trades of narcotic drugs". This set of practices though not narrowed to the youths but majorly driven and made to flourish by the attendant number of youths who are in haste not only to make a living but flamboyant, thriftless and profligate lives detrimental to norms, values and society itself. Premised on the danger they herald for the society, the paper appraised the numerous unholy practices rampant among youths in Nigeria and their impacts on the society. Exploratory method was made use of; secondary source was employed and inferences were drawn via qualitative analysis. Findings revealed that exponential decadence among youths is directly proportional to the culture of prostitution, regime of internet fraud (yahoo-yahoo), kidnapping for ransom, social revolution of gambling etcetera. The paper concludes that unholy practices among youths have constituted a nuisance in no small measure to the society. The paper however advocates that the government at all levels should up their game in training youths in the vocation that would make them engage and reduce the surge in such practices in the society.
\end{abstract}

Keywords: scheming, heartbeat, streamliner, plagues, rattle, exponential, nation.

Rezumat. Înainte de anul 1990 și până la sfârșitul anilor 1990, Nigeria a fost devastată de ceea ce era cunoscut atunci ca „Fraude gratuite avansate” botezate (419) și „Comerțul cu stupefiante". După mai bine de două decenii, un nou set de practici nefaste și-au găsit drumul în structura societății și s-au dovedit în mod constant a fi mai rele decât duo-ul „419” și „meserii de stupefiante”. Acest set de practici, deși nu este restrâns la tineri, este condus în mare măsură și făcut să înflorească de către numărul mare al tinerilor care se grăbesc nu numai să-și câștige existența, ci și să trăiască lipsit de griji, de economii, în detrimentul normelor, valorilor și societății în sine. Premisă cu privire la pericolul pe care îl anunță pentru societate, articolul a evaluat numeroasele practici nesfârșite în rândul tinerilor din Nigeria și impactul acestora asupra societății. S-a folosit metoda exploratorie; a fost utilizată o sursă secundară, iar inferențele au fost analizate prin metode calitative. Rezultatele au arătat, că decadența exponențială în rândul tinerilor este direct 
proporțională subculturii prostituției, regimului fraudelor pe internet (yahoo-yahoo), răpiri pentru răscumpărare, revoluția socială a jocurilor de noroc etc. Lucrarea concluzionează, că practicile nefaste în rândul tinerilor au constituit o pierdere pentru societate. Cu toate acestea, lucrarea susține că guvernul de la toate nivelurile ar trebui să-și susțină politica în formarea tinerilor prin vocația care i-ar face să se angajeze și să reducă aceste practici nefaste pentru societate.

Cuvinte cheie: schemă, bătăi ale inimii, raționalizator, ciume, zgomot, exponențial, națiune.

\section{Introduction}

There is no downplaying the fact that youths are the cerebral core of any nation. No wonder, serious nations prefer to model their lots around them. This confirms the saying that if youths are involved in scheming of things in a society, her future is more than assured. It is not only because they are the future, but that they are the life cord connecting or bridging the ageing and the infants in the society. The same goes with the argument that they are the protective belt conserving the past and dictating the future of any nation. According to the Nigeria Second National Youth Policy, youths are considered the valued possession of any nation or region, without them, there can be no future because they are the center of reconstruction and development [1]. This point to the more reason generally they are addressed as the "future leaders".

However, with a slight shift in conception, they are not only the future but the today of nations. This assertion is predicated on the revolution and changes that have taken place in many countries whereby youths not only play important roles in the social, cultural and economic landscape of such nations but also made to dominate and shape their political decisions. However, as virile as youths could be for any nation, they could also be so terrifying if not properly managed or utilized in a manner that can contribute to the strides and development of the nation. "Youths" are considered as the heartbeat of any nation. Any serious government that wants to succeed must take youth development very seriously. Any nation without youth development would be heading for a disaster; if properly managed can be very useful and if not can be disastrous. They are also the greatest asset any meaningful nation can boast of [2].

Rendering account of how the youth have been disillusioned and incapacitated the system, the former Vice-Chancellor of Adekunle Ajasin University, Akungba-Akoko, Professor Femi Mimiko, in an interview with the Punch Newspaper, maintained that "youth unemployment is about 40 percent... You have an army of citizens that is completely disoriented, frustrated, and angry, expressing their outrage in terrorism, kidnapping, 'YahooYahoo', and all manners of brigandage. Ours is the textbook definition of state capture, where tiny governing elite runs the system in its interest and for its good [3]. It is a fact that a sizeable population of Nigerians is made up of youth. In the words of Price, males and females in the age range of 15 to 34 are estimated to constitute more than one-third of the Nigerian population. He stated further that, these youth make up the largest proportion of people in Nigeria, with a gender distribution of $51.6 \%$ female and $48.4 \%$ male [4].

Going by these statistics, the core part of the society (youth) are expected to be in the forefront or driving seat, piloting the socio-economic, political, cultural and other spheres of human endeavours. Be that as it may, in Nigeria today, this narrative is not meant to be. All the same, and with the foreknowledge that the nation is run milk-dry by few at the expense of over 180 million others which are significantly constituted by youths 
destined for no direction in a straightjacket manner society, little would one wonder in the huge number embracing unholy practices. Amazingly in recent times, there have been exponential increase in both the number of unholy practices and youths compare to the relatively low number who are engaged in decent jobs or vocations. That is, the number of youths engaging in enterprises that are considered amoral to the human dignity and the society is unprecedented.

Going by the unmatched figure of youths actively involved in sharp practices, the country's name has not only been tarnished but her identity further enmeshed among the comity of nations. The dysfunctional in the system is exemplified in the glaring fact starring us in the face that an innocent Nigerian embarking on an adventure elsewhere in the world is categorized as a potential suspect of these antisocial practices. In the light of the disservice it has done to the country's identity amidst nations, and having reached a point that it practically becomes the newest youth-plagues spreading like Harmattan bush fire the country is now engulfed and battered with, the paper seeks among other things to discuss some of the unholy practices prevalent among youths in Nigeria that in turn makes her a disjointed society. Nevertheless, useful recommendations capable of stemming the tide were advocated.

\section{Objectives of the Study}

The broad objectives of the study are:

To clarify the concepts 'youth', 'unholy practices', and 'society'

To examine some of the unholy practices prevalent among youth in Nigeria

To advocate feasible measures that can stem the flow of unholy practices in Nigeria.

\section{Methodology}

The methodology used was exploratory analytical technique; secondary source was adopted for data collection. This was done through library sources, books, journals, magazines, conference papers and other works applicable to the study. Internet sources were also found helpful for the inquiry. The gathered data were critically and thoroughly analyzed which ensured an objective conclusion.

\section{Significance of the study}

The inquiry focused on the unholy practices among youth in Nigeria which invariably has for ages been responsible for many of the anomalies and malfunction in the system, and has assumed a worrisome dimension requiring all hands to be on deck for control and its possible curtailment. And as a response to the worries as expressed from various quarters, the inquiry came up with possible steps meant to address the problem. Therefore, it will be of immense value to the body of existing knowledge most especially in fields like criminology, sociology, peace and conflict studies, security and developmental studies. Again, the inquiry will also be practically handy to policymakers, stakeholders, researchers, scholars and students who are anxious about how to not only stem the flow but to nick in the bud the unholy practices among youth in the society.

\section{Scope of Study}

It is inferable via the topic that the study primarily captured the unholy practices among youth in Nigeria and the peril it portends for the system. Given this, the work applies only to the Nigerian clime and not universal. Similarly, the study covered the period of late 1990s when multiplex and new set of sharp practices started crippling into the Nigerian society till date. 


\section{Concepts Clarification \\ Youth}

Universally, the concept 'youth' is one of the widely discussed concepts in the field of humanity and social science. Lately, fields like peace and conflict studies, sociology, demography and social statistics plus other social science field have had controversial submission of the concept. A multidisciplinary concept with multidimensional grasping and connotation that not only depends on the individuals doing its interpretation but its narratives largely rest on the perspective and discipline it is being reviewed. It is this complexity avouched in the concept that makes it not ascribable with precise definition or meaning. According to Amzat \& Ali, "such difficulty stems from the fact that the concept has political, sociological, legal, gerontological, demographical and even theoretical dimensions [5].

Recognizing the differential and relativity enshrouded in the concept, the United Nations UN gave two distinct definitions as thus; youth as a period of transition from the dependence of childhood to adulthood's independence and youth as those persons between the ages of 15 and 24 years [6]. Looking at the latter conception, it could be argued that it does not capture a universal sense of the term because there is no homogeneity in youth. In other words, the age bracket varies from culture to culture and also depends on a variety of factors like political, socio-economic and geographical locations. The African Youths Report AYR 2009 organized by United Nations Economic Commission for Africa UNECA defined "youths" as people between 15 and 39 years of age [7].

It is a fact that youth notion is usually defined differently by many countries. For instance, countries in Africa such as Ghana, South Africa and Tanzania see their youth as those between 15 and 35 years of age; Botswana defined hers as persons between 15 and 25 years of age; Nigeria defined it as those between 18 and 30 years of age. In this sense, every country's guess about the notion youth becomes good as another in so far it is considered as a 'social group' of people who doesn't enjoy the parental care like children but rather take responsibility for whatever they decide to go with. With the cognizance of the general definition of youth been evasive and difficult to come by, its unique attributes and traits are expatiated as thus, greater physical strength, greater knowledge acquisition propensity, faster rate of learning, faster reaction time, innovative proneness, love for adventure and preference for boldness, minimal risk aversion, less fear of failure, less conservation and others [2].

\section{Unholy}

Before a comprehensive exposition of the term "unholy practice(s)", it will be apposite and levelheaded to first clarify the adjective "unholy". Unholy could be interpreted as meaning the following; an expression of disapproval, displeasing or unpleasant of something or about conduct of somebody; having to do with committed cruel acts; exhibition of abhor and dishonest dispositions. Other synonymous words interchangeable of unholy are impious, atrocious, dreadful, profane, cruelty, outrageous, unhallowed, immoral, base, unconsecrated etcetera.

\section{Unholy Practices}

In the context of the social order, they are acts and actions that are morally abnegated, censured and typically regarded as anti-social deeds. In other words, traits exhibition which is not only severely detrimental to workings and functionalism of society 
but also portends exact capsize or counterclockwise of norms, values and virtues cherished in a societal setup. Unfortunately, Nigeria represents fairly of a fertile ground where varieties of religion are made to flourish profoundly. Despite the multiplex of religion in the nation, unholy and sharp practices most especially among the youths continue to flourish at a disturbing and alarming speed. Hence, an illustration which nothing could be fitter than is that of a resemblance of a 'dilemmatic society'. The dilemma stems from the fact that the nation is overstressed with different denominations of worship centers which in a way a commensurate with the number of unholy practices panning out lately.

Ordinarily, with the religious activities dominating the nation as if it is the country's gross domestic product (GDP), one would have expected that by now the nation should have become holier than Jerusalem. Unfortunately, the opposite is the scenario because worldliness and materialism remains the driver and conductor of many Churches left alone the congregations. An indicator of this is that when one critically examines the lives of bigwigs in the religious circle, one is left with no alternative than to marvel with the traits oozing out which symbolizes that of worldly life. It is however not unfathomable that religious institution is a tunnel that eases the smooth passage and encourages the meteoric rise of unholy practices among youths. This assertion hinges on the reality that fraudsters, men of the underworld and questionable character are openly showered encomium like saints especially when they donate handsomely from their proceeds to evangelism.

The misplaced priority by religion is an attendant fact that its main objective has been defeated long ago. Therefore, it becomes a matter of ends and not the means for churches in celebrating the successful members of congregation. As crucial, sensitive and decisive as religion is to societal wellbeing, it is horrendous that the same streamliner of society has abetted unholy practices in eating deep into the fabric of society like a venom strike from typical America's super rattlesnake penetrating its way through the body of a delicious prey. Be that as it may, the implication of the massive number of youths engaging in these counterproductive ventures is that a sizeable number of destinies are permanently destroyed; the society rub off the peace as it were in the past and turned "state of nature" which is brutish, nasty and short in the words of Thomas Hobbes.

\section{Society}

The term society refers to the human configuration and system of interrelationship that brings everyone together thereby becoming an indivisible entity, unit or an organization. It could also mean the totality of human interaction, thoughts, feelings, norms and values shared under a single umbrella (society) that connects us. The idea of a society developed from the actuality that human beings are set apart from other animals by being social, able to reason, internally integrate and live together within a given territory which thus invariably defeats all individualistic tendencies. A society is a self-sufficient, selfperpetuating, and internally autonomous system of social relations. Such a system distinguishes a population occupying a specific territory; but as a system of social relations, the society is distinct from territory or population. The society is the structure of relations through which the population of members is internally organized as joint occupants of a given area [8].

\section{Theoretical Framework}

Establishing a justification and theoretical base for unholy practices among youth, the study adopted Social disorganization theory. The theory is germane to the study 
because the crux, underlining idea and myth clouding unholy practices among youths and other related anomalies perpetrated by them is fittingly embedded, captured with precision and comprehensively explained within the realm of the theory.

\section{Social Disorganization Theory}

The theory of social disorganization emanates through the works of sociologists Robert Park and Earnest Burgess in the early 1900s at the University of Chicago. They were preoccupied with the explanation of criminality and other social problems that existed in the cities about the social and environmental factors. However, the theory was further thickened, broadened and given a facelift which ever made its application possible to more social problems and not limited to the purview of crime by a duo of Chicago scholars; Clifford Shaw and Henry McKay (1942) who helped to popularize the social disorganization approach to delinquency. They began their research in Chicago during the 1920s, when the city was full of newcomers and foreign-born immigrants. Most of the newcomers congregated in the central city area, occupying old, deteriorated housing with many health and environmental hazards. Shaw and McKay scientifically studied crime within this changing urban environment [9].

To understand a socially disorganized society, some primary dynamics ought to exist within such milieu. This includes high rates of residential turnover, a heterogeneous population, a high level of moral decadence and a high level of defiant to constituted law. Cullen and Agnew put it in a clearer perspective by opining that to understand the crime causation in a better perspective is not to study individuals within a system but rather to lay emphasis on the whole society itself [10]. However, Cloward and Ohlin enthused that studies in the United States, England and elsewhere have shown that there exist strong correlations between high crime rates and such social disorganization factors as alienation, poverty, disorder, broken homes, and unemployment [9].

Substantiating this view, Igbo noted that "social disorganization refers to a breakdown in normal and habitual way of life. It is associated with the breakdown of conventional norms and values as a result of industrialization, globalization and urbanization of Nigeria as a nation [11]. The societal disorganization occasioned by these dynamics have had a far arching consequence on the Nigerian cultural value in no small measure, by displacing the much cherished and revered indigenous communal living and substituting it with alien culture that is embedded with sophisticated misdemeanour delinquent behaviours and unholy practices which have arguably become routine among youths in the country. It is rather not platonic but empirically visible that unholy practices such as prostitution, internet fraud (yahoo-yahoo), kidnapping, gambling, amongst others, are prevalent among youths. Having done some of these practices for long, they have been able to discern that there lays a great lucrative and life-insured escapade for them.

\section{Examination of Unholy Practices among Youths in Nigeria}

It is a general verdict that the youths constitute the largest percentage of the Nigeria population, most especially when it is divided into the active and less active contributors to the Gross Domestic Products (GDP). The same could be said when it comes to examining the class of people who are actively involved in cultivation, propagation and promotion of myriads of unholy practices, diminishing values and distorting culture in the country. Although, the idea of having youth as dominant or centerpiece of the population of the country is not in any case a natural indicator of minus or negativity on the socio-economic, 
cultural lifestyle and other important sectors in the country. Rather, it makes every sector buoyant and rock-solid because of their potent and agile nature.

However, the argument is that whenever such a huge number (youths) which ordinarily supposed to be an aplomb for sustainability and development is left unchartered in such a way that it could positively imprint on the nation, then, the neglect, unutilized and involuntariness of such a humongous number will ultimately comes back to haunt the nation perilously. The arbitrariness or uncontrolled youth has been and of course, is the manure which is regularly nurturing and multiplying unholy practices amidst youths in Nigeria.

\section{Culture of Prostitution}

The simplest, modest and most enduring definition of prostitution is the view that "prostitution stems out from a manner of lending (for money or other purposes) of one's body to other persons so that they can satisfy their sexual needs [12].

Whenever the phrase "prostitution" or "harlot" gets mentioned, the ensuing bell that rings in the ear is usually succeeded by the trademark "the world's oldest profession". An eyebrow may be raised as to what makes it universally qualified as the oldest profession without an attraction of quantum contradiction. However, such a puzzle as regards the truism of the assertion is readily dispelled going by the biblical affirmation of prostitution as the oldest profession ever practiced in the ancient world. This ground was thickened by the situation of ancient Israel as the commonplace of prostitution. The popular illustration that recurrently comes to reckoning is that of Judah and Tamar accounted in Genesis 38:14-26. In that period, prostitutes would wait at the side of highways for travelers or passersby who normally engaged them in sex, and after the sexual encounter with the prostitutes, they are obliged to exchange them with kid goat or in the absence of a valuable which was a measure of transaction in those days and only the rich could afford them.

The acknowledgment by the bible as the very first profession becomes the justification of the practice for some people who have never for once questioned its sanctity or morality, little would one then wonder about the encouragement and promotion given by these amoral individuals in the society to the youths who are hell-bent on eking out a livelihood from the unethical practice of prostitution. As a result of this biblical pedestal, inferences have been drawn as arguments and grounds by some people towards establishing the legality and licensing of prostitution in many societies. But again the biblical credence does not in any way establish the legality, sanctity and of course, the nobleness of the first-ever vocation practiced on the surface of the earth. It could be argued that the recognition of the profession by the bible has further established the phenomenon as one of the fewer regular contradictions that exist between the holy book and the modern culture or society. This is unconnected with the fact that every discussion on the phenomenon makes the bible a fertile basis or precedence for future reference.

However, turning attention away from the biblical perspective and approaching issues with what is obtainable and acceptable to the typical African cultural society of which Nigerian society belongs, there is no gainsaying that prostitution is not a culturally specific phenomenon. In essence, it is a global issue that affects every culture. Even as ubiquitous and prevailing as it may appears to be, major African cultures Nigeria inclusive disapproved, frown and speaks ill of the practice of prostitution in no small volume. In African countries including Nigeria, where many cultures speak against sex work, the 
presence of a large number of commercial sex workers have now become a major social issue [13]. The indulgence of youths in this antisocial, deviant and unholy practice unarguably pits it against the culture or society. "Prostitutes have a separate subculture with norms and values that are directly opposed to that of the larger society to the extent that they often run foul of the laws of the society [14].

Though a major contravention of deviance to the laws of the society, which may have been occasioned and given rise to as a result of the prevalent moral decadence, economic hardship, high poverty condition and the push for money so as to meet up with the existential demands in the society. "Prostitution is based on the economic exchange of relationships between the prostitute and the customer, one participating for pleasure and the other for money [14]. In essence, it was a trade-only reserved for the downtrodden and members of the lower class of the society who could not have been able to make ends meet without engaging in sex in exchange for money. However, one which was not very rampant until lately in the society is the surge of the phenomenon or the occupation of prostitution among able, educated and sophisticated youths in the Nigerian society.

The festering and upsurge in the practice has seen so many youths become professionals in the unholy act of prostitution. Some of the notable groups under which they are identified are:

- Escort workers: This particular group of prostitutes is very expensive due to the home service they render. Their contacts are given to clients through hotel staff serving as intermediaries or facilitators between them.

- Students Class (Aristos): They are found virtually in every higher institution of learning, sometimes their clients could include lecturers with whom they exchange sex for marks, and they on many occasion fantasized with politicians and wealthy people in the society.

- Beach Boys (gigolos): This particular group is made up of young and active boys who like "aristos" get paid for sexual service rendered to "sugar mummies".

- Call Girls: This group is independently classified and sophisticated prostitutes who make use of social media and print media outlets in advertising their products and services for customers to patronize.

\section{Epidemic of Internet Fraud (yahoo-yahoo)}

The striking conception that birthed and eventually produced the invention of information and communication technology (ICT) was a well thought out one which conceived the world where economy strengthened, social revolution promoted, new political ideology introduced, technological inclined human beings are given a facelift and are driven by technology projected towards actualizing maximum transformation, increased output and development across boards. "The introduction of new technology into the business or commercial arena often offers the promise of a better world, thereby challenging, in the process, our imagination and enhancing human expectations. In this sense, the internet revolution was construed to be an era that would usher in an unprecedented social transformation: new economy, new politics, new world order, indeed a new and advanced species of human beings whose personalities will be dependent on the computer and whose expertise would be transported across the borders of space and time by the power of the internet [15]. 
From the basic disposition that the internet will be helpful, rewarding and ensuring development across boards, there has been a slight shift from this focus in Nigeria. It has been made to be understood that the internet represents something of a double edged sword which is both developmental and detrimental to the subscriber of it. The ticklish youths have since turned the idea to a detrimental avenue where fraud can be perpetrated. That is the initiative has since been reconstructed, reconfigured and channeled to accommodate their incriminating or negative penchant for eking out ends meet through transactions which are targeted at swindling the unsuspecting foreigners off their valuables and money. This scenario was exemplified in the expressions which have clearly shown that the relationship between technology and society has proved not to be metaphysical but quite materialistic instead [15]. It is worth stressing that a sizeable number of youths who see the internet as a soft landing for practicing fraudulent activities have taken their fraudulent enterprise by storm and far, they now go as far as engaging in diabolical means of enchanting the unsuspecting clientele with shams (juju) to depose them of their valuables.

The upsurge of yahoo-yahoo among youths has led to tainted in the identity of Nigerians most especially the ones living abroad as the country is however seen and given the toga of the most fraudulent and crime-friendly nation in the world. The index was arrived at as a result of the huge number of imposters' activities showing on the cyberspace. Nigeria has been fashioned as the origin of the most fraudulent spam mails appearing in the cyberspace [16]. Though it could be said that fraud and sharp practices have been in existence for a long period in the country, but the accessibility made possible through the internet for fraudsters to reach out to a great number of clients has been given a big boost even without their identity shown. The indulgence in the yahoo-yahoo act has reached a worrying dimension considering the percentage of youths engaging in the dastard venture. Lately, it has become a haven for graduates who could not secure job upon graduation, due to this dire situation they faced they are easily tricked and recruited into the atrocious enterprise. The worst of it all is the initiation of both undergraduates and the secondary students into the disdain vocation.

\section{Kidnapping for Obtaining Ransom}

Kidnapping, a typical unholy practice is fast becoming a deeper problem by the day for the country, as the phenomenon is a matter of existent rather than platonic act massively cultured by the youths in the society. Consequently, the high-level concentration among the youths has become a source and subject of concern for everyone in the Nigerian society. Coining out a suitable explanation for the phenomenon may however not be straight-jacketed or an easy task because as problematic as the phenomenon is to the society, so also an all-encompassing definition becomes to the definer because it is dimensional and opinionated based. Upholding this view, Ottuh \& Aitufe illustrated that defining kidnapping is problematic... The word poses many definitional problems about a country's legal and moral viewpoints as well as the availability of other variances such as hostage-taking, hijacking, abduction etcetera [17]. Kidnapping varies from country to country [18].

Therefore, explaining it within the Nigerian context becomes imperative because no philosopher can philosophize beyond his or her immediate milieu. This definition practically becomes handy in this respect. Kidnapping can be seen as false imprisonment in the sense 
that it involves the illegal confinement of individuals against his or her own will by another individual in such a way as to violate the confined individual's right to be free from the restraint of movement [19]. Shifting the searchlight from the definition and sway the direction of causes of kidnapping, it could be argued that there are diverse causes for kidnapping especially when the phenomenon is expanded or viewed under a wide scope. The causes could include proliferation of small and light weapons, poverty, youth unemployment, materialism and loss of societal values. However, when the causal connection is narrowed down to the youth's involvement in the business, one is left with no causation than youth unemployment and an urge for materialism. It is in the respect of this that Odoh expertly observed that, underlying these acts of callousness (kidnapping) is the fact that the youths are idle and live in a society where a man's worth or importance is measured by his material possession [20].

Going by Odoh's statement "a man's worth or importance is measured by his material possession". Little would one then be taken aback by the volume of social revolution by the youths most significantly the unemployed individuals who have found the unholy practice of kidnapping to be a soft landing enterprise to better their economic situation. It is essential to note that the negative thoughts of youths making quick cash via kidnapping did not occur spontaneously, rather it evolved, got redefined and eventually face-lifted as a result of being unemployed of many smart, intelligent and strategic thinking graduates who have since remained technocrats in the unholy practice. It is however glaring in the face that kidnapping is rampant among youths in the country as it is considered a very lucrative business capable of sustaining their existential needs. Yet, it has to be stressed that this kind of unholy practice does not only appear on the illegitimate side of the coin but very well abhor societal values, norms and parenthetically antithetical to the development of the society.

\section{Social Revolution of Gambling}

The act of gambling refers to any practice that involves placing of bet on a game or its variance usually induced and driven by money purpose. "It is the staking of money on the outcome of games or events involving chance or skill. Similarly, it is seen as the wagering of money or other belongings on chance activities or events with random or uncertain outcomes [21]. Available records have shown that the phenomenon of gambling has long been in existence in the history of mankind. Tracing its first practice, Omanchi and Okpamen opined that, the earliest record of gambling appears in ancient Rome, recounting stories of peasants and emperors gambling with dice and huge gambling debts and the fights that broke out over them [22].

Before its introduction in Nigeria, it was considered an antisocial practice and was assiduously campaigned against and discouraged by the duo of Christianity and Islamic religions, because of the tendency to make people cut corners and amassed wealth through illegitimate means. Despite the forewarning coming from the religious movement, towards the tail end of the $20^{\text {th }}$ Century, the Nigerian government via Chapter 22, section 236 of the Criminal Code Act endorsed the practice for income and tax drive purposes [23]. Worryingly, the unholy practice of gambling which has become a novel and chief social revolution among Nigerian youths nowadays has assumed larger than what the society could cope with. The meteoric rise and upsurge of gambling among youths in recent times which has been unprecedented in the country could be said to be directly proportional to the 
attendant proliferation and path for youths to regularly indulge in gambling. Some of such paths are:

- Lottery bet: Bet for doling out rewards by chance or risk which could be by any of these forms; casting of dice, tickets, cards lots, numbers etcetera.

- Casino: A social establishment where gambling takes place like playing card games, snooker games, slot machines etcetera.

- Gambling on animals: This activity is often done by predicting animal race results and placing a stake in the outcome.

- Draft game: It is a board game for two players in which the players race their seeds from start to finish and the seeds are moved towards opposition territory, the first player to have his seeds exhausted automatically becomes the loser. Though a recreation and leisure game, but becomes gambling if and only if money is placed and risked as a wager by the players concerned.

Needless to say that in the time past, gambling was done clandestinely in the pool shops which were not as ubiquitous as the gambling outlets like bet9ja, nairabet, surebet247, goldenwinnersbet, merrybet, betking, betpawa, sportybet et-cetera that have become worship centers for the youths. The worst of it all is that most of these bet companies have devised easy means where it is made possible for youths to place bet and other transactions online through phones, tablets and other computer applications.

\section{Conclusion}

Nigerian society suffers from high moral and ethical debauchery which stems out of unholy practices amidst youths. Practices like prostitution, kidnapping, internet fraud (yahoo-yahoo), gambling and others are venoms that have over and over again strike at the core of society thereby making societal cherished values, norms and morals eroded at an alarming speed. Besides, the country's name, image and identity have been tainted and given a bad outlook amidst the comity of nations, mediocrity celebrated at the expense of excellence and ingenuity made to play second fiddle to craftiness. It is also glaring in the face of everyone that with the saturation of these practices among youths-, there seems to be no heydays but rather a bleak future for the country in so far these practices continue to deepen in the Nigerian society.

\section{Feasible Measures that can stem the Flow of Unholy Practices in Nigeria}

- It is flagrant there is a high level of morals and values distortion in the Nigerian society, the setback stems from the failure of institutions that are hypothetical to instilling morals in the young ones. A decisive stare at institutions like family, school, religion, Non-governmental organizations (NGOs) and National Orientation Agency (NOA) etcetera shows that all have failed in their respective capacities at ensuring a better society. Therefore, for Nigeria as a nation to regain its normal pedestal as expected of a sane society, all the mentioned institutions and more would have to embrace revamping or go back to the drawing board and play significant roles as per values integration and restoration of morals which remains vital in shaping the future of not only the youths but that of the entire society too.

- Government has to raise its bar and do more in creating employment and skill acquisition training for its teeming youth's population. The proposal became necessary because of the alarming percentage of the youths who are wanting when 
it comes to engagement in productive ventures. By implication of this derisory condition, they are cheaply lured to practices like prostitution, kidnapping and 'yahoo-yahoo' which are detrimental to everyone in the society. To however deemphasize these practices, there has to be encouragement coming their way in form of job creation and vocational skills capable of taking care of their existential demand.

- Another approach that government has to take conscientious effort is in the direction of stern prosecution of people who have been investigated and found guilty of internet fraud (yahoo-yahoo) to serve as a deterrent to others contemplating the act. The government through the various agencies assigned to wage war against the scourge seems to be exhibiting a double standard approach. This is because many of the personnel of these agencies are found in the habit of collecting bribe from the fraudsters leaving out those who couldn't negotiate their way through to face judgment. Therefore, if the war against internet fraud would have to be won, then it has to be sincere prosecution whereby no one cares about whose ox is gored.

- Lastly, the monumental consequences of the gambling epidemic have been felt all over the nation. It has now reached a point where almost all and no one is left out of the practice. The alarming indulgence has seen a sizeable number of underage who should normally not engage in gambling do it on regular basis. This worry has partly been aided by the non-compliance and regulation by the National Lottery Commission as per guiding gambling. Based on the observation that there is no strict adherence to the law and dictate regulating gambling, it has become imperative for the government through the National Lottery Commission to come out with a more serious approach at abating the exponential increase in youths engaging in gambling.

\section{References}

1. Second National Youth Policy Document of the Federal Republic of Nigeria Published by the Federal Republic of Nigeria, 2009.

2. Agbegbedia A. O. \& Ejemezu, C. I. Youth Development Policy: A Panacea for Managing Youth Violence in Nigeria International Journal of Arts and Commerce, 2019, Vol. 8, No.9, pp. 59-73.

3. Mimiko F. I once publicly criticized someone who introduced me as Gov Mimiko's brother Available on https://punch.com/topics/interviews/life-times/ Retrieved May 23, 2020.

4. Price, R.A. Youth employment needs in Nigeria K4D Helpdesk Report 691. Brighton, UK: Institute of Development Studies, 2019.

5. Amzat J. \& Ali A.A. Youth and Political Change in Nigeria: Historical Note and Critical Discourse AFFRIKA: Journal of Political, Economics and Society, 2016 Volume 6, Number 2, pp. 119137.

6. UN 'World Youths Report- Young People's Transition to Adulthood: Progress and Challenges'; New York; UN, 2007.

7. UNECA African Youths Report: Expanding Opportunities for and with Young People in Africa. Addis Ababa: UNECA, 2009.

8. Smith M.G. Pluralism in Pre-colonial African Societies. In Kuper and Smith eds. Pluralism in Africa, Berkeley and Los Angeles: University of California Press, 1969 pp. 91-151.

9. Cloward R.A \& Ohlin, L .E. Sociological Theories: Social-Structural Explanations for Criminal Behaviour Available on http//:www.ablongman.com/glickie retrieved June 21, 2020.

10. Cullen, F.T \& Agnew, R. Criminological Theory: Past to Present. New York, Oxford University Press, 2011.

11. Igbo E.U.M. Introduction to Criminology Nsukka: University of Nigeria Press, 2007. 
12. Tiosavljevic D. Prostitution as a Psychiatric Situation: Ethical Aspects Psychiatric Dambina, 2016 Vol. 28, No. 4, pp. $349-356$.

13. Bagudo A.A.\& Yusuf M.A. Addressing Prevalence of Prostitution in Nigeria Through Non-Formal Education Provisions European Journal of Education and Development Psychology, 2019 Vol.7, No.2, pp. 1-10.

14. Kangiwa A.G. The Socio-Economic Effects of Prostitution in Nigeria European Journal of Research in Social Sciences, 2015 Vol. 3, No. 5, pp. 70-83.

15.Jegede A. E. \& Olowookere Cyber Risks and Fraud in the Nigeria's Business Environment: A Postmortem of Youth Crime Journal of Social and Development Sciences, 2014 Vol. 5, No. 4, pp. 258-265.

16. Abdulkabir, O.S. The Impulsive Upsurge of Yahoo-Yahoo in the $21^{\text {st }}$ Century: Islamic Perspective African Journal of Criminology and Justice Studies, 2019 Vol. 12, No. 1, pp. 91-104

17. Ottuh P.O \& Aitufe, V.O Kidnapping and Moral Society: An Ethno-Religious Evaluation of the Nigerian Experience. European Scientific Journal, 2014 Vol. 1, no. 14 pp.420-433.

18. lyang J.D \& Abraham, U.E "the Social Problem of Kidnapping and its Implications on the Socio-Economic Development of Nigeria: A Study of Uyo Metropolis". Mediterranean Journal of Social Sciences, 2013 Vol. 4 No 6.

19. Ngwama, J.C. Kidnapping in Nigeria: An Emerging Social Crime and the Implications for the Labour Market. International Journal of Humanities and Social Science, 2014 Vol. 4 No 1 pp. 133 - 145.

20. Odoh I. D. Kidnapping in Nigeria and its roots Causes, 2010 Available on http://tncp.net/Articles/tabid/1800/articleType/Articleview/ retrieved September 27, 2020.

21. Bankole, E.T. Patterns and Prevalence of Gambling Behaviour among Youths in South-West Nigeria: A Case Study of Youths in Oyo and Ekiti State British Journal of Psychology Research, 2019 Vol. 7, No. 2, pp. 22-46.

22. Omanchi S.A. \& Okpamen, K.O. The Changing Patterns of Gambling in Benue State: The Case of Emerging Role of ICT (Information and Communication Technology) in Contemporary Makurdi Metropolis American Association for Science and Technology, 2018 Volume 5, Issue 2, pp. 29-36.

23. Criminal Code Act, Laws of the Federation of Nigeria Government, 1990 Available on http://www.commonlii.org/ng/legis/num_act/cca115/ retrieved 29 $9^{\text {th }}$ September, 2020. 